\title{
Determination of Reduced Glutathione and Glutathione S-transferase of Poultry Birds Exposed to Permethrin Insecticide
}

\author{
Ethelbert U. Ezeji ${ }^{*}$, Ernest A. Anyalogbu, Tobias N. Ezejiofor, Justina U. Udensi \\ Department of Biotechnology, Federal University of Technology, P.M.B 1526, Owerri, Nigeria
}

\begin{abstract}
The experiment was carried out to determine the effect of a permethrin insecticide on reduced Glutathione (GSH) and Glutathione S-transferase (GST) activity in the liver and serum of poultry birds. Six weeks old poultry birds (broilers) weighing between $400-600 \mathrm{~g}$, divided into four groups of five birds each. The poultry birds were exposed for 30 days to different concentrations $(1,5$ and $10 \%$ ) of a locally manufactured insect powder called 'Rambo' which contains $0.6 \%$ permethrin. The control group had no insecticide added to their feed. The levels of reduced glutathione in the treated groups were significantly higher than those in the control group $(p<0.05)$ in both the serum and liver of the poultry birds. Liver and serum Glutathione S-transferase activity was significantly lower $(\mathrm{p}<0.05)$ in 1,5 and $10 \%$ insecticide concentrations as against the control. The total liver protein was significantly higher at all levels of pesticide exposure compared with the control while serum protein content was significantly higher at 5 and $10 \%$ insecticide concentrations. Results of this experiment confirmed the use of GST as a biomarker in ecological evaluation of environmental pollutants.
\end{abstract}

Keywords Pesticides, Xenobiotics, Detoxification, Biomarkers, Enzymes

\section{Introduction}

There is an increasing concern about the ecological effect of the use of pesticides. It has been reported that pesticide ingestion either by direct or indirect exposure may lead to generation of reactive oxygen species (ROS), which are detrimental to the health of humans and non-target organisms (Otitoju and Onwurah, 2007). Bioaccumulation of pesticides in the food chain can lead to potentially adverse effects in humans and useful animals (Palmeira, 1999). As a non-target animal, poultry birds (domestic fowls) stand the risk of pesticide poisoning because of their tendency to pick up pesticide contaminated food and other items in the environment (Ezeji et al., 2011).

Reduced glutathione (GSH) and glutathione S-transferase (GST) play important roles in detoxification of xenobiotics (Slater and Sawyer, 1970; Meister and Anderson, 1983; Manno et al., 1985; Bompart et al., 2000). GST catalyzes the addition of glutathione to endogenous xenobiotics (Satheesh et al, 2011; Aydemir and Kavrayan, 2009). They are particularly at high levels in the liver (Hayes et al., 2005). GST is thought to play a physiological role in initiating the detoxification of potential alkylating agents (Trakshel and

* Corresponding author:

ucheezeji@yahoo.com (Ethelbert U. Ezeji)

Published online at http://journal.sapub.org/ajb

Copyright (C) 2012 Scientific \& Academic Publishing. All Rights Reserved
Maines, 1988; Habig et al., 1974). Due to their high sensitivity to environmental pollutants, GSH and GST have been used as markers of toxic effects of exposure to various xenobiotics (Slater and Sawyer, 1970; Meister and Anderson, 1983; Manno et al., 1985).

This study was undertaken to investigate the effect of permethrin exposure on non-target animals like poultry birds by determining the activities of GSH and GST. Permethrin is an insecticide in the Pyrethroid chemical family. It is considered a type 1 pyrethroid. Pyrethroids are one of the most important classes of insecticide accounting for $17 \%$ of the world insecticide market (Davies et al., 2007). Synthetic pyrethroid insecticides are chiral compounds with multiple asymmetric positions (Hu et al, 2010). Rambo insect powder is a popular insecticide in Nigeria, containing $0.60 \%$ permethrin as its active ingredient. Results obtained from this study will also confirm the use of Glutathione $\mathrm{S}$-transferase as a biomarker in ecological risk assessment of pesticide contaminated environment.

\section{Materials and Methods}

\section{Test sample}

The pesticide used for this study was a locally made insect powder called 'Rambo' which is indicated by its manufacturer to contain $0.60 \%$ permethrin as its active ingredient. Rambo insect powder is a product of Gongoni 
Company Limited, 89A Sharade Industrial Estate, Phase III, Kanu Nigeria.

\section{Formulation of Contaminated Poultry feeds}

Commercially available poultry feed was contaminated by weighing out a definite amount of the feed and mixed with a graded percentage of the insecticide to give 1, 5 and $10 \%$ (w/w) contamination respectively. Feed for the control contained no Rambo insect powder.

\section{Experimental Animals}

Six weeks old poultry birds (Gallus domesticus) weighing between 400-600 g were bought from poultry farm market in Owerri, Nigeria. The birds were maintained on commercial poultry feed (starter feed) for about two weeks before the commencement of the experiment. They were then randomly divided into four groups containing five (5) birds per group in a battery cage where they were fed ad libitum with $0,1,5$ and $10 \%(\mathrm{w} / \mathrm{w})$ contaminated feeds, respectively, for a period of 30 days. The group fed with uncontaminated feed served as the control. The birds were provided with adequate water supply.

\section{Preparation of liver homogenate}

After 30 days of exposure, the birds were sacrificed by decapitation; the blood was collected and the liver extirpated. The hepatic tissues were homogenized in $\mathrm{KCl}$ [10 $\mathrm{mM}]$ phosphate buffer $(1.15 \%)$ with ethylene-diamine tetra acetic acid (EDTA, pH 7.4) and centrifuged at 12, $000 \mathrm{rpm}$ for 60 min. The supernatant was used to assay for reduced glutathione, glutathione s-transferase and total protein concentration. The assay was also carried out using the serum from the collected blood.

\section{Glutathione determination}

Reduced glutathione was measured according to the method of Ellman (1959) as described by Bulaj et al. (1998).

\section{Determination of glutathione s-transferase activity}

Glutathione s-transferase activity was determined according to the procedure described by Habig et al. (1974). The specific activity of GST was expressed as $\mu \mathrm{mol}$ GSH-CDNB (1-chloro-2, 4-dinitrobenzene) conjugate formed $/ \mathrm{min} / \mathrm{mg} /$ protein using an extinction coefficient of 9.6 $\mathrm{mM}^{-1} \mathrm{~cm}^{-1}$.

\section{Total protein determination}

Serum and liver protein contents were assayed by the Biuret method as described by Gornall et al., 1949. Bovine serum albumen (B.S.A) was used a standard protein.

\section{Statistical Analysis}

The results were expressed as mean \pm standard error of means (SEM). The data were statistically analysed using Student's t-test with the program statistical package for social sciences (SPSS) version 17. The data means were considered different at $\mathrm{p}<0.05$.

\section{Results}

\section{Reduced Glutathione level}

Generally, glutathione was found to be higher in the liver than in the serum (Tables 1 and 2). There was significant increase in serum GSH $(\mathrm{p}<0.05)$ at $1 \%$ and $5 \%$ pesticide contamination compared to the control (Table 1). The serum GSH level was however reduced at $10 \%$ pesticide contamination. A similar trend was observed with liver where GSH levels were significantly higher at $1 \%$ and 5\% pesticide contamination (Table 2). The highest glutathione level was recorded in the group with $1 \%$ pesticide exposure $(77.45 \mathrm{~g} / \mathrm{dL}$ for the serum and $309.78 \mathrm{~g} / \mathrm{dL}$ for liver respectively).

Table 1. Serum protein, Glutathione and Glutathione S-transferase of poultry birds exposed to different concentration of Rambo Insecticide.

\begin{tabular}{lccc}
\hline $\begin{array}{c}\text { Pesticide } \\
\text { Conc }\end{array}$ & Protein & GSH & GST \\
\hline Control & $35.926 \pm 0.51^{\mathrm{a}}$ & $47.234 \pm 0.41^{\mathrm{a}}$ & $17.00 \pm 1.77^{\mathrm{a}}$ \\
$1 \%$ & $37.227 \pm 0.44^{\mathrm{a}}$ & $77.447 \pm 0.42^{\mathrm{b}}$ & $14.30 \pm 0.90^{\mathrm{b}}$ \\
$5 \%$ & $40.351 \pm 0.49^{\mathrm{b}}$ & $53.617 \pm 0.91^{\mathrm{c}}$ & $12.10 \pm 0.82^{\mathrm{b}}$ \\
& & & \\
$10 \%$ & $40.872 \pm 0.26^{\mathrm{b}}$ & $44.255 \pm 0.42^{\mathrm{a}}$ & $10.00 \pm 1.83^{\mathrm{b}}$ \\
\hline
\end{tabular}

Values expressed as standard error values \pm of the samples $(\mathrm{N}=4)$

${ }^{a-c}$ Means within a column with no common superscript differ significantly at $\mathrm{p}<0.05$

Table 2. Liver protein, Glutathione and Glutathione S-transferase of poultry birds exposed to different concentration of Rambo Insecticide.

\begin{tabular}{lccc}
\hline $\begin{array}{c}\text { Pesticide } \\
\text { Conc }\end{array}$ & Protein & GSH & GST \\
\hline Control & $140.579 \pm 1.44^{\mathrm{a}}$ & $188.936 \pm 0.72^{\mathrm{a}}$ & $27.20 \pm 58.90^{\mathrm{a}}$ \\
$1 \%$ & $175.984 \pm 0.79^{\mathrm{b}}$ & $309.787 \pm 0.58^{\mathrm{b}}$ & $23.90 \pm 0.1 .96^{\mathrm{b}}$ \\
$5 \%$ & $198.893 \pm 0.73^{\mathrm{c}}$ & $214.468 \pm 0.39^{\mathrm{c}}$ & $19.40 \pm 1.53^{\mathrm{c}}$ \\
$10 \%$ & $149.95 \pm 0.99^{\mathrm{d}}$ & $177.021 \pm 0.1^{\mathrm{d}}$ & $16.00 \pm 6.74^{\mathrm{d}}$ \\
\hline
\end{tabular}

Values expressed as standard error values \pm of the samples $(\mathrm{N}=4)$.

${ }^{\mathrm{a}-\mathrm{d}}$ Means within a column with no common superscript differ significantly at $\mathrm{p}<0.05$

\section{Glutathione S-transferase activity}

There was significant reduction $(\mathrm{p}<0.05)$ in GST activity with increase in pesticide contamination in both the serum (Table 1) and the liver (Table 2). Serum GST reduced from $17.00 \mathrm{mg} / \mathrm{mL}$ in the control to $10.00 \mathrm{mg} / \mathrm{ml}$ in the birds exposed to $10 \%$ pesticide concentration. On the other hand the liver GST reduced from $27.20 \mathrm{mg} / \mathrm{ml}$ in the control to $16.00 \mathrm{mg} / \mathrm{mL}$ in those fed with $10 \%$ pesticide concentration.

\section{Total protein content}

The serum and liver protein content of the birds are shown in Tables 1 and 2 . The serum protein ranged from $35.93 \pm 0.51 \mathrm{~g} / \mathrm{dL}$ (control) to $40.87 \pm 0.26 \mathrm{~g} / \mathrm{dL} \quad(10 \%$ contamination). There was significant $(\mathrm{p}<0.05)$ increase in serum protein content at $5 \%$ and $10 \%$ pesticide exposure respectively (Table 1) while the liver protein content increase significantly $(\mathrm{p}<0.05)$ at all levels of pesticide 
exposure (Table 2). The highest liver protein $(198.893 \pm 0.73$ $\mathrm{g} / \mathrm{dL}$ ) was however recorded at $5 \%$ pesticide concentration.

\section{Discussion}

This research was carried out to determine the effect of exposure of "RAMBO" insecticide on poultry birds which is one of the non-target animals vulnerable to pesticide poisoning. The total serum and liver protein contents were found to be higher in the birds exposed to different concentrations of the pesticide than the control. Otitoju and Onwurah (2007) however reported a reduction in rat plasma protein due to different concentrations of Rambo insecticide. The protein content of kidney of newly hatched chick was unaffected by permethrin exposure (Khushid, 2003).

Glutathione (GSH) and Glutathione S-transferase are among the major antioxidant defences. Glutathione plays a very important role in the detoxification and elimination of xenobiotics (pesticides). GSH levels were found to be significant higher $(\mathrm{p}<0.05)$ in birds exposed to pesticides at $1 \%$ and $5 \%$ concentrations but lower than the control at $10 \%$ pesticide exposure. The reduction in GSH with increase in pesticide concentration (10\%) is in line with the report of Kumar et al. (2010) that exposure to xenobiotics caused a depletion of GSH levels in poultry birds. El-Demerdash (2011) also reported a reduction in GSH content of rats exposed to a mixture of synthetic pyrethroids and organophosphate insecticides. Reduction in GSH level is an indication that detoxification is going on.

Glutathione S-transferases (GSTs) are ubiquitous multifunctional enzymes which play a key role in cellular detoxification (Tang and Bi, 2003) and especially chemical xenobiotics like pesticides (Ezemonye and Tongo, 2010). The major activity of GST is the conjugation of compounds with electrophilic centers to the tripeptide glutathione (Oakley, 2011). The glutathione conjugates are metabolized further to mecapturic acid and then excreted. There was a significant reduction $(\mathrm{p}<0.05)$ in GST activity in both the serum and liver in birds exposed to pesticide. Otitoju and Onwurah (2007) reported a reduction in plasma GST activity in rats exposed to permethrin pesticide. Elevated levels of GST activity have been associated with resistance to all the major classes of insecticides (Ranson and Hemingway, 2005). Our study revealed that the higher the concentration of pesticide the lower the GST activity. It is pertinent to note that the reduction in GST activity was more pronounced in the liver. This is due to the fact that major cellular detoxification takes place in the liver.

\section{Conclusions}

This study has shown that pesticide exposure has the potential of disrupting the cellular function of organisms by affecting the activities of detoxifying enzymes in the bodies of these organisms. It has also shown that the potential risk of pesticide exposure can be assessed by monitoring the levels and activities of agents of cellular detoxification such as Glutathione and Glutathione S-transferase.

\section{REFERENCES}

[1] Aydemir T, Kavrayan D. 2009. Purification and characteriza tion of glutathione-s-transferase from chicken erythrocyte. Artif. Cells Blood Substit. Immobil. Biotechnol., 37: 92-100

[2] Bompart GJ, Prevot DS, Bascands JL. 2000. Rapid automated analysis of glutathione reductase, peroxidase and S-transfera se activity: Application to cisplatin-induced toxicity. Clin. Biochem., 23: 501-504

[3] Bulaj G, Kortemme T, Goldenberg DP. 1998. Ionization: Reactivity relationships for cysteine thiols in polypeptides. Biochemistry, 37: 8965-8972

[4] Davies TGE, Field LM, Usherwood PNR, Williamson MS. 2007. DDT, pyrethrins, pyrethroids and insect sodium channels. IUBMB Life, 59: 151-162

[5] Ellman GL. 1959. Tissue sulfhydryl groups. Arch. Biochem. Biophys., 82: 70-77

[6] El-Demerdash FM. 2011. Oxidative stress and Hepatoxicity Induced by Synthetic Pyrethroids-Organophosphate Insectici des mixture in Rat. Journal of Env. Sc. \& Health, 29: 145-158

[7] Ezeji EU, Anyalogbu EA, Duru CM. 2011. Use of biochemical biomarkers in the ecological risk assessment of permethrin pesticide exposure. J. Toxicol. Environ. Health Sci., 3: 14-17

[8] Ezemonye L, Tongo I. 2010. Sublethal effects of endosulfan and diazinon pesticides on Glutathione-S-Transferase (GST) in various tissue of adult amphibian (Bufo regularis). Chemosphere, 81: 214-217

[9] Gornall AG, Bardawill CS, David MM. 1949. Determination of serum protein by means of the biuret reaction. J. Biol. Chem., 177: 751-766

[10] Habig WJ, Pabst MJ, Jacoby WB. 1974. Glutathione S-transferase, the first enzymatic step in mercapturic acid formation. J. Biol. Chem. 249: 7130-7139

[11] Hayes J, Flanagan J, Jowsey I. 2005. Glutathione transferases. Ann. Rev. Phamacol. Toxicol., 45: 51-88

[12] Hu F L, Li C, Wang Q, Zhang X, Zhao M. 2010. Enantiosele ctive induction of oxidative stress by permethrin in rat adrenal pheochromocytoma (PC12) cells. Environ. Toxicol. Chem., 29: 683-690

[13] Khushid A. 2003. Effect of permethrin treatment on the kidney of newly hatched chick (Gallus domesticus). Journal of Applied Science, 3: 317-330

[14] Kumar MR, Reddy GA, Anjaneyulu Y, Reddy GD. 2010. Oxidative stress induced by Lead and Antioxidant potential of certain Adaptogens in poultry. Toxicol Int'l. 17(2): 45- 48

[15] Manno M, Bertazzon A, Burlina A, Galzigna L. 1985. Interaction of low doses of ionizing radiation and carbon tetrachloride on liver superoxide dismutase and glutathione peroxidase in mice. Enzyme, 34: 107-112 
[16] Meister A, Anderson ME. 1983. Glutathione. Ann. Rev. Biochem., 52: 711-760

[17] Oakley A. 2011. Glutathione transferases: A structural perspective. Drug Metab. Rev., 43(2): 138-151

[18] Ranson H, Hemingway J. 2005. Mosquito glutathione transferase. Mtds Enzymol., 401: 226-241

[19] Satheesh P, Rao AA, Sridhar GR, Srinivas K, Akula CS. 2011. Sequence analysis and homology modeling Gallus gallus glutathione s-transferase. Adv. Exp. Med. Biol., 680: 405-410

[20] Slater TF, Sawyer BC. 1970. The hepatoxic action of carbon tetrachloride stimulatory effect of carbon tetrachloride on lipid peroxidation in microsomal suspensions. FEBS Lett., 11: $132-136$
[21] Otitoju O, Onwurah INE. 2007. Glutathione S-transferase (GST) activity as a biomarker in ecological risk assessment of pesticide contaminated environment. Afr. J. Biotechnol., 6: $1455-1459$

[22] Palmeira CM. 1999. Herbicide-induced mitochondria and cellular liver toxicity: A review of paraquat, dinoseb and 2, 4-D effects. J. Toxicol. Substs. Mech., 18: 187-204

[23] Tang ZH, Bi Q. 2003. Molecular Behavior of Insecticide Action. Shanghai Far-East Publishing House, Shanghai, China, pp: 200

[24] Trakshel GM, Maines MD. 1988. Characterization of glutathione S-transferase in rat kidney: Alteration of composition by cis-platinum. Biochem. J., 252: 127-136 